\title{
Truncated (des-[27-31]) C-peptide is not a major secretory product of human islets
}

\author{
M. Paoletta ${ }^{1}$, S. E. Kahn ${ }^{2}$, P. A. Halban ${ }^{1}$ \\ ${ }^{1}$ Louis Jeantet Research Laboratories, University of Geneva Medical Centre, Geneva, Switzerland \\ 2 Division of Metabolism, Endocrinology and Nutrition, Department of Medicine, \\ Veterans Affairs Puget Sound Health Care System and University of Washington, Seattle, Washington, USA
}

\section{Abstract}

Aims/hypothesis. It has been suggested that C-peptide is bioactive and that such bioactivity is lost when the last five amino acids are removed. In rats, $\mathrm{C}$-peptide is truncated in beta-cell granules leading to the loss of these last five residues and secretion of des-[27-31]C-peptide. The aim of this study was to determine whether this truncated form of C-peptide was also a secretory product of human islets.

Methods. Plasma from healthy subjects, patients with Type II (non-insulin-dependent) diabetes mellitus or insulinoma and cord blood was analysed by HPLC and ELISA. This method allows for separation and quantification of intact C-peptide and des-[27-31]C-peptide. Human islets were pulse-chased and secretion stimulated by a mixture of secretagogues. Radioactive products secreted to the medium were analysed by HPLC and the relative amount of intact and truncated C-peptide measured.

Results. The proportion of total C-peptide immunoreactivity comprised of des-[27-31]-C-peptide was $1.5 \%$ or less in all plasma samples, except for that from one patient with insulinoma where it was $4.2 \%$. The proportion of radiolabelled des-[27-31]C-peptide released from isolated islets was less than $1 \%$.

Conclusion/interpretation. In contrast to the situation in rats, des-[27-31]-C-peptide is not a major secretory product of human islets and its contribution to total circulating C-peptide is not increased in Type II diabetes or in patients with insulinoma. [Diabetologia (2002) 45:1523-1527]

Keywords Type II diabetes, insulinoma, proinsulin, insulin, newborn.
The biosynthetic precursor of insulin, proinsulin, is normally processed to equimolar amounts of insulin and C-peptide. The biological activity of insulin is self-evident. Proinsulin has clearly been shown to have biological activity but this is reduced relative to insulin. It has been suggested that C-peptide is also a bioactive peptide, (for reviews see $[1,2]$ ) capable,

Received: 25 April 2002 / Revised: 3 July 2002

Published online: 9 October 2002

C) Springer-Verlag 2002

Corresponding author: P. A. Halban, PhD, Louis Jeantet Research Laboratories, University of Geneva Medical Center, 1 rue Michel Servet, 1211 Geneva 4, Switzerland.

E-mail: philippe.halban@medecine.unige.ch

Abbreviations: ACN, Acetonitrile; KRB, Krebs-Ringer bicarbonate; TFA, trifluoroacetic acid. among several postulated actions, of altering renal $[3,4]$ and muscle-cell function $[5,6]$ and preventing vascular and neural dysfunction [7-9].

A putative C-peptide receptor that could mediate such activity has been studied [10-12] and there is evidence to suggest that binding and biological activity depends on the last five residues [10, 13] with Glu27 playing a particularly important role [12]. In rats, we have shown truncation of C-peptide within beta-cell granules [14]. This results in the secretion of approximately $10 \%$ of total C-peptide as the form without its five C-terminal amino acids (des-[27-31]$\mathrm{C}$-peptide) along with the other conventional secretory products, proinsulin and insulin [14].

With the identification of des-[27-31]-C-peptide as a normal beta-cell secretory product in rodents [14] and the possibility that the five terminal amino acids 
are critical for binding of $\mathrm{C}$-peptide to its putative receptor and for bioactivity [10,13], it was essential to know whether this truncated form of the peptide is a circulating product in humans. For this purpose, we undertook studies in healthy subjects, individuals with Type II (non-insulin-dependent) diabetes mellitus, newborns and subjects with insulinomas to find out whether the truncated form of C-peptide is present in plasma. In the course of these assessments, we failed to identify des-[27-31]-C-peptide as a major circulating product in humans. To ensure that the lack of truncated C-peptide in plasma was not due to rapid clearance or degradation in vivo, we also carried out in vitro experiments using human islets and found that they do not release des-[27-31]-C-peptide in quantifiable amounts.

\section{Subjects and methods}

Subjects. Plasma samples were obtained from apparently healthy subjects (three adults and two newborns) as well as from three individuals with Type II diabetes and two with insulinomas. All studies were approved by Institutional Review Boards at the respective institutions and with written informed consent for the sampling of blood.

In the healthy adults and individuals with Type II diabetes, blood was drawn from 2 to 5 min following commencement of administration of arginine ( $5 \mathrm{~g}$ intravenously over $30 \mathrm{~s}$ ). Plasma from the newborns was obtained at the time of delivery by the sampling of cord blood. In the two subjects with insulinomas, blood was sampled from the right hepatic vein after administration of $0.025 \mathrm{mEq} \mathrm{Ca}{ }^{2+}(1 \mathrm{mg}$ calcium gluconate) per kg body weight through a cannula placed in the lienalis artery in Patient 1 and the gastroduodenal artery in Patient 2.

Pulse-chase studies on human islets. Human islets were obtained from the Islet Distribution Center (University of Miami, Fla., USA). These islets were isolated from a brain-dead, heart beating, multiple organ donor with no known history of diabetes. For this experiment, islets were washed three times with Krebs-Ringer bicarbonate buffer, $0.25 \%$ bovine serum albumin (BSA), $10 \mathrm{mmol} / \mathrm{l}$ Hepes (KRB) containing $16.7 \mathrm{mmol} / \mathrm{l} \mathrm{glu}-$ cose and then pre-incubated in this same buffer for $15 \mathrm{~min}$ at $37{ }^{\circ} \mathrm{C}$. Islets were then pulse-labelled for $20 \mathrm{~min}$ at $37^{\circ} \mathrm{C}$ with $50 \mu \mathrm{Ci}\left[{ }^{3} \mathrm{H}\right]$ leucine (specific radioactivity $100-200 \mathrm{Ci} / \mathrm{mmol}$ from Anawa Trading, Wangen, Switzerland) in $200 \mu \mathrm{l} \mathrm{KRB}$, $16.7 \mathrm{mmol} / \mathrm{l}$ glucose. After washing three times with $\mathrm{KRB}$, $1.7 \mathrm{mmol} / \mathrm{l}$ glucose $\left(4^{\circ} \mathrm{C}\right)$, the islets were chased for $4 \mathrm{~h}$ at $37{ }^{\circ} \mathrm{C}$ (KRB, $1.7 \mathrm{mmol} / \mathrm{l}$ glucose) prior to stimulation for $15 \mathrm{~min}$ with $16.7 \mathrm{mmol} / \mathrm{l}$ glucose, $0.1 \mathrm{mmol} / \mathrm{l}$ isobutylmethylxanthine (IBMX), $5 \mu \mathrm{M}$ forskolin, $0.1 \mu \mathrm{mol} / \mathrm{l}$ phorbol 12-myristate 13 -acetate (PMA) and $10 \mathrm{mmol} / \mathrm{l}$ arginine. The samples were centrifuged (1000 rpm, $10 \mathrm{~min}$ ) to pellet islets and cellular material after which the supernatant was removed and kept frozen for subsequent analysis.

HPLC. Prior to HPLC analysis, 4-5 $\mathrm{ml}$ aliquots of plasma were concentrated and partially purified by passage through Sep-Pak cartridges (Waters Division, Millipore, Milford, Mass., USA). Cartridges were primed with $5 \mathrm{ml}$ acetonitrile (ACN) followed by $5 \mathrm{ml}$ distilled $\mathrm{H}_{2} \mathrm{O}$. Up to $5 \mathrm{ml}$ plasma was then applied to the cartridge followed by $5 \mathrm{ml} 10 \% \mathrm{ACN}$ and then $5 \mathrm{ml} 0.1 \%$ trifluoroacetic acid (TFA), $0.1 \%$ BSA. Peptides were eluted with $5 \mathrm{ml}$ of $40 \% \mathrm{ACN}$ into glass tubes pre-coated with $1 \%$ BSA. ACN was removed by evaporation using a water pump connected to a Speedvac (Savant, Farmingdale, N.Y., USA) for $30 \mathrm{~min}$ and then lyophilised under high vacuum. The dried pellets were reconstituted in $300 \mu \mathrm{l}$ of $0.1 \%$ TFA, $0.1 \% \mathrm{BSA}$ and stored at $-20{ }^{\circ} \mathrm{C}$.

HPLC separation of C-peptide and des-[27-31]-C-peptide was carried out using a LiChrospher 100 RP-18 column (Merck, Darmstadt, Germany). Peptides were eluted isocratically with $72 \%$ component A $\left(50 \mathrm{mmol} / 1 \mathrm{H}_{3} \mathrm{PO}_{4}, 100 \mathrm{mmol} / \mathrm{l}\right.$ $\mathrm{NaClO}_{4}, 10 \mathrm{mmol} / \mathrm{l}$ heptanesulphonic acid, $\mathrm{pH} 3.0$ ) and $28 \%$ component B (90\% ACN:10\% $\left.\mathrm{H}_{2} \mathrm{O}\right)$. Synthetic human C-peptide and human des-[27-31]-C-peptide were the generous gift of Zymogenetics (Seattle, Wash., USA). Fractions $(0.5 \mathrm{ml})$ were collected every $30 \mathrm{~s}$ in tubes containing $100 \mu \mathrm{l} 0.6 \%$ BSA. After evaporation and lyophilisation (see above), fractions were reconstituted with $0.1 \mathrm{ml}$ phosphate buffered saline (PBS), $0.1 \%$ BSA and the $\mathrm{pH}$ adjusted to 7.4 by addition of $10 \mu \mathrm{l}$ of $1 \mathrm{mmol} / \mathrm{l} \mathrm{NaOH}$.

Using this approach of sample concentration followed by chromatographic separation, a proportion of the sample is inevitably lost. We have assessed recovery of both intact and des-[27-31]-C-peptide during this process and have found that the loss affects both peptides equally when they coexist in a sample in varying proportions. Recovery from Sep-Pak was $95.9 \pm 3.1 \%$ (mean \pm SEM; $n=6$ ) while recovery from the stage involving HPLC followed by lyophilisation and reconstitution of the fractions was $63.3 \pm 7.9 \%(n=6)$. It is believed that this loss occurs predominantly in the lyophilisation and reconstitution steps of the procedure. In any event, no residual C-peptide-like immunoreactivity could be eluted from the column during the washing procedure.

Assays. Blood was collected on EDTA and aprotinin, separated and stored at $-70^{\circ} \mathrm{C}$ before being assayed. Plasma immunoreactive insulin was measured by radioimmunoassay, using the charcoal separation method [15]. C-peptide was quantified in plasma and in fractions eluted from the HPLC by ELISA (Kit number K6218 from Dako, Ely, UK). This assay recognises both intact and des-[27-31]-C-peptide on an equimolar basis (data not shown) and has a minimal detectable concentration of $17 \mathrm{pmol} / \mathrm{l}$ and intra-assay and inter-assay coefficients of variation of 3.3-5.7 and 4.6-5.3\% respectively.

Limits of detection. We assessed the limits of detection of the relative proportion of intact and truncated C-peptide based on the assay and the number of fractions over which the two peptides eluted from HPLC. For the plasma samples, the limit of detection was calculated relative to the total amount of intact C-peptide eluting from HPLC. This value was $1.1 \%$ des[27-31]-C-peptide for the sample with the lowest amount of intact C-peptide eluting from HPLC and a percentage lower than this in all other instances. For all data on plasma samples, the values were either above the detectable limit for that individual or have been expressed as lower than the minimal detectable level. In the isolated islet pulse-chase experiment, a similar calculation indicated a lower limit of $1.0 \%$ for labelled des[27-31]-C-peptide relative to intact C-peptide radioactivity.

\section{Results}

In vivo human studies. The phenotypic characteristics and the basal and arginine-stimulated plasma immunoreactive insulin concentrations as well as the stimulated C-peptide concentrations in the apparently heal- 
Table 1. Clinical characteristics and basal and arginine-stimulated plasma immunoreactive insulin and C-peptide responses in three healthy subjects and three patients with Type II diabetes

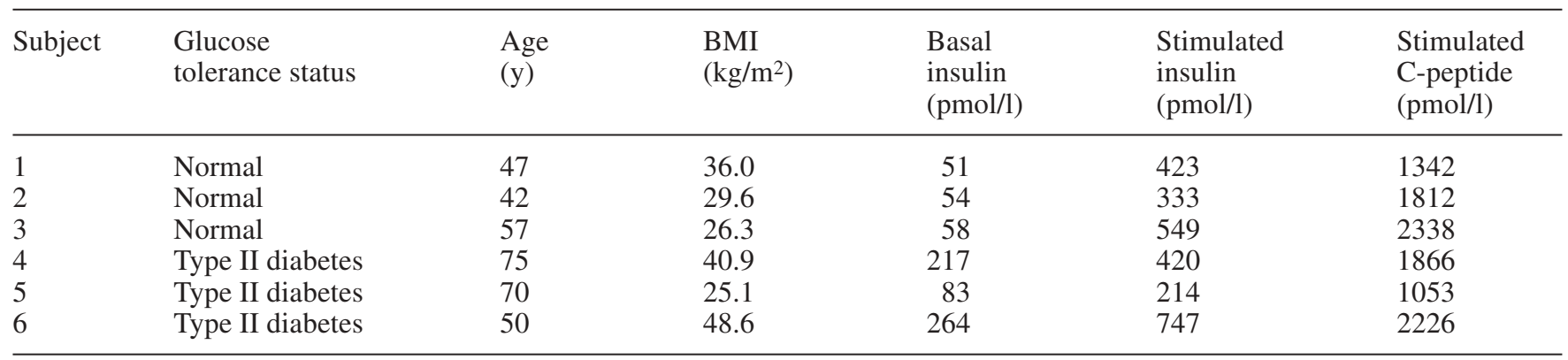

thy subjects and Type II (non-insulin-dependent) diabetes mellitus are listed in Table 1 . In all these individuals, stimulation with arginine was associated with an increment in plasma immunoreactive insulin. The average magnitude of this increase was 7.1-fold in the healthy subjects and 1.4-fold in those patients with Type II diabetes. Stimulated C-peptide concentrations ranged from 1053 to $2338 \mathrm{pmol} / \mathrm{l}$ and were not different between the two groups. Thus, both groups showed a secretory response to arginine but this was lower in the patients with Type II diabetes. Despite this difference in responsiveness, stimulated C-peptide concentrations were within the same range and sufficient for subsequent HPLC analysis.

HPLC analysis of arginine-stimulated plasma from all six individuals listed in Table 1 showed a peak corresponding to intact human C-peptide. By contrast, there was very little detectable immunoreactive material eluting in the expected position of des-[27-31]C-peptide. In the three apparently healthy subjects, the proportion of total C-peptide immunoreactivity eluted from HPLC that was comprised of des-[27-31]C-peptide was less than $0.2,1.2$ and $1.5 \%$ respectively while in the three patients with Type II diabetes it was less than $0.2,0.3$ and $0.4 \%$ respectively. A typical profile from a healthy subject is illustrated in Fig. 1A. To exclude the possibility that the truncated form of the peptide was being preferentially lost during the processing and analysis of the sample, synthetic des[27-31]-C-peptide was added to another aliquot of plasma from the same subject and processed in parallel. As illustrated in Fig. 1B, following the identical protocol, truncated C-peptide was recovered by HPLC in spiked human plasma and eluted at the same time point as synthetic des-[27-31]-C-peptide in buffer. Thus, it seems that des-[27-31]-C-peptide is not an appreciable circulating product in healthy subjects and patients with Type II diabetes.

We had previously shown that neonatal rat islet cells and transformed rat beta cells (INS-1 cells) produce and secrete greater proportions of des-[27-31]-C-peptide than do adult rat islets [14]. Thus, to determine whether the lack of truncation of C-peptide in humans could be a function of maturation of the beta cell, we first carried out HPLC analysis on cord blood obtained at the time

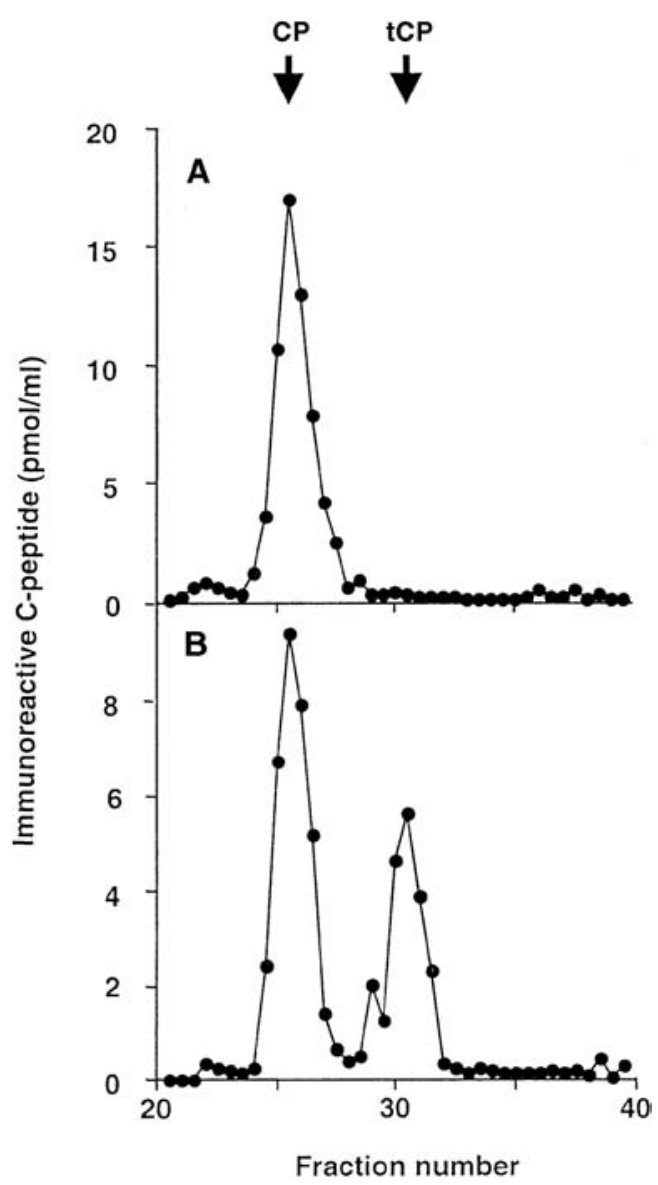

Fig. 1A, B. HPLC analysis of C-peptide in human plasma. A Plasma from a healthy subject was pre-purified and concentrated and then analysed by HPLC. Immunoreactive C-peptide was measured in eluted fractions $(0.5 \mathrm{~min} ; 0.5 \mathrm{ml})$ using an ELISA method that recognises both intact and truncated (des-[27-31]-C-peptide) with equal affinity. B Synthetic des[27-31]-C-peptide was added to a second aliquot of the same plasma and the mixed sample then analysed as in (A). Arrow heads show the elution times for intact C-peptide (CP) and des-[27-31]-C-peptide (tCP)

of delivery from two newborns. However, while intact C-peptide was present on HPLC, des-[27-31]-C-peptide was not detectable in either sample. Given these negative results, we then examined samples obtained from the hepatic artery in two subjects with histologically confirmed insulinomas (Table 2). These samples 
Table 2. Clinical characteristics of insulinoma patients and fasting test

Fasting test

\begin{tabular}{lllllll}
\hline Subject & $\begin{array}{l}\text { Age } \\
(\mathrm{y})\end{array}$ & $\begin{array}{l}\text { BMI } \\
\left(\mathrm{kg} / \mathrm{m}^{2}\right)\end{array}$ & $\begin{array}{l}\text { Basal insulin } \\
(\mathrm{pmol} / \mathrm{l})\end{array}$ & $\begin{array}{l}\text { End of test } \\
\text { insulin } \\
(\mathrm{pmol} / \mathrm{l})\end{array}$ & $\begin{array}{l}\text { Basal } \\
\text { glucose } \\
(\mathrm{mmol} / \mathrm{l})\end{array}$ & $\begin{array}{l}\text { End of test } \\
\text { glucose } \\
(\mathrm{mmol} / \mathrm{l})\end{array}$ \\
\hline 1 & 84 & 24.2 & 142 & 153 & 5.0 & $1.7(\mathrm{after} 11 \mathrm{~h})$ \\
2 & 70 & 19.4 & 85 & 75 & 2.4 & $1.6(\mathrm{after} 15 \mathrm{~h})$ \\
\hline
\end{tabular}

Both patients were diagnosed with insulinoma and were negative for urinary sulphonylurea during the fasting test. The fasting tests were ended when patients developed symptoms of neurohypoglycaemia (at the times given in parentheses). The

patients underwent surgical removal of the tumours with histological confirmation of the diagnosis. Blood glucose was normalized post-operatively and the patients became asymptomatic

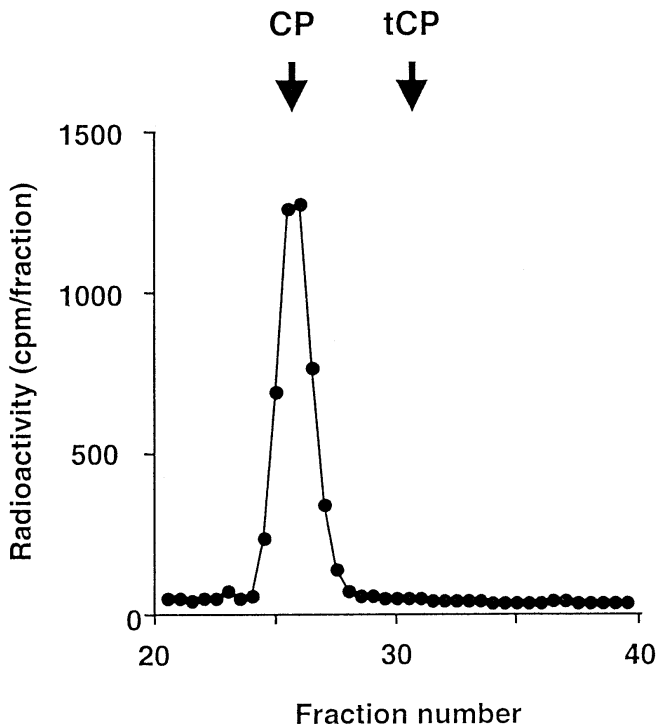

Fig. 2. HPLC analysis of radioactive products released from pulse-labelled human islets. Human islets were pulse-labelled (20 min $\left[{ }^{3} \mathrm{H}\right]$ leucine), chased for $4 \mathrm{~h}$ under basal conditions and then stimulated by secretagogues for $15 \mathrm{~min}$. Radioactive products in the stimulated medium were analysed by HPLC. Arrow heads show the elution times for intact C-peptide (CP) and des-[27-31]-C-peptide (tCP)

were obtained following infusion of calcium, a known stimulant of insulin release, directly into the arterial supply of the pancreas. These infusions were associated with an increment in plasma immunoreactive insulin from $471 \mathrm{pmol} / \mathrm{l}$ prior to $3237 \mathrm{pmol} / \mathrm{l} 30 \mathrm{~s}$ following the start of the calcium infusion for insulinoma Patient 1 and from 117 to $1594 \mathrm{pmol} / \mathrm{l}$ at the same time-point for insulinoma Patient 2. In the post-calcium infusion samples, the plasma C-peptide concentrations were 6420 in the first patient and $3960 \mathrm{pmol} / \mathrm{l}$ in the second. In both these samples, intact C-peptide was detected by HPLC with only small quantities of des-[27-31]-C-peptide which accounted for $1.1 \%$ and $4.2 \%$ of total C-peptide immunoreactivity eluted by HPLC.

Pulse-chase studies with human islets. The essential absence of detectable quantities of truncated C-peptide in peripheral plasma from healthy subjects could not exclude the possibility that the normal betacell produces des-[27-31]-C-peptide but this form of the peptide is totally cleared from plasma prior to sampling from a peripheral vein. Therefore, we carried out pulse-chase experiments followed by HPLC of secreted products to determine whether des[27-31]-C-peptide is produced by normal human islets. As illustrated in Fig. 2, radioactively labelled material eluted in fractions corresponding to intact C-peptide but very little radioactivity was detected in fractions in which synthetic des-[27-31]-C-peptide eluted. This amounted to less than $1.0 \%$ of total $\mathrm{C}$-peptide radioactivity, which was as such below the minimal detectable limit of the system. Therefore, if normal human islets do truncate C-peptide to des[27-31]-C-peptide as part of the normal biosynthesis of insulin from proinsulin, this process is minor.

\section{Discussion}

The results of this study indicate that des-[27-31]C-peptide is not a major circulating form of C-peptide in humans. Further, the in vitro data obtained using healthy human islets would suggest that human beta cells do not truncate C-peptide to a substantial extent. Plasma obtained from two patients with an insulinoma also contained relatively small amounts of this truncated product, amounting to 1.1 and $4.2 \%$ of total C-peptide immunoreactivity in samples drawn from the hepatic vein.

These findings are somewhat in contrast to studies we previously reported in perfused rat pancreas from which approximately $10 \%$ of C-peptide was released as this truncated form [14]. This relative lack of truncation of human C-peptide could have been due either to absence of the appropriate enzyme (or enzymes) in human beta-cell secretory granules or because the human peptide is not a good substrate for this enzyme (or enzymes). Based on our previous finding that rat insulinoma (INS-1) cells expressing human proinsulin truncate $31 \%$ of human C-peptide compared with $37 \%$ of endogenous rat C-peptide I [14], we believe that it is more likely that human beta cells do not contain the necessary activity of enzyme (or enzymes) required 
for C-peptide truncation. In one patient with an insulinoma, the degree of truncation appeared to be slightly greater but this could also have been related to the different site of sampling compared to the healthy subjects and Type II diabetic patients. However, this difference is small relative to that observed when we studied rat insulinoma (INS-1) cells compared to normal rat islets in that truncated C-peptide amounted to $37 \%$ of total C-peptide after $2 \mathrm{~h}$ of chase in INS-1cells but only 3.8 and $8.5 \%$ after $2 \mathrm{~h}$ and $4 \mathrm{~h}$ respectively of chase in isolated rat islets [14].

In these studies we also examined samples of cord blood obtained from newborns at the time of delivery. The rationale for doing this was that we previously observed that neonatal rat islet cells truncate $\mathrm{C}$-peptide to a greater extent than do adult rat islet cells [14]. The lack of appreciable amounts of des-[27-31]-C-peptide in umbilical cord blood suggests either that this process does not occur in man or that all truncated C-peptide had been cleared from plasma prior to sampling.

Our failure to identify des-[27-31]-C-peptide as a major product of the normal human beta cell and a lack of a difference in the proportion of this truncated product relative to intact C-peptide in patients with Type II diabetes contrasts with the situation regarding proinsulin processing. Normally, proinsulin processing is incomplete so that some 2 to $5 \%$ of insulin immunoreactivity within the secretory granule is comprised of proinsulin and its conversion intermediates [16]. In Type II diabetes, this is increased some two to three fold and it has been debated whether this increase is due to intrinsic changes within the beta cell or decreased residence time of the secretory granule within the cell [16]. The lack of a difference in C-peptide truncation in healthy subjects and patients with Type II diabetes speaks against any change that could be responsible for the inefficient processing of proinsulin affecting, in a major way, the activity of the enyzme(s) involved in truncation and that are known to function within granules.

It is possible that the quantity of truncated C-peptide we found in hepatic vein plasma could represent less than that being released by the insulinoma as a result of selective hepatic extraction of the truncated form of the peptide. We consider this unlikely given that intact C-peptide is not cleared to any appreciable extent by the liver. The findings do suggest that the amounts of des-[27-31]-C-peptide are likely to be too low to possibly make this a clinically useful tool for diagnosing insulinomas. These findings of very low concentrations of truncated C-peptide also have implications for clinical studies examining the potential bioactivity of intact C-peptide. The presence of intact C-peptide as essentially the only detectable form in plasma obtained from healthy subjects and patients with Type II diabetes suggests that inactivation by truncation in the beta-cell secretory granule [13] is not likely to be of biological importance and that it does not contribute to the disease state of Type II diabetes.
Acknowledgements. The authors thank Dr. M. Donath from the University of Zurich for providing plasma from the insulinoma patients. This work was supported in part by NIH grants DK-02654 and DK-17047, the Medical Research Service of the Department of Veterans Affairs and by Grant 3200-061776.00 from the Swiss National Research Fund. M. Paoletta was supported by a scholarship in the MD.PhD programme of the Swiss Academy of Medical Sciences.

\section{References}

1. Wahren J, Johansson BL (1998) New aspects of C-peptide physiology. Horm Metab Res 30: A2-A5

2. Wahren J, Ekberg K, Johansson J et al. (2000) Role of C-peptide in human physiology. Am J Physiol 278: E759E768

3. Johansson BL, Sjöberg S, Wahren J (1992) The influence of human C-peptide on renal function and glucose utilization in Type I (insulin-dependent) diabetic patients. Diabetologia 35: 121-128

4. Ohtomo Y, Aperia A, Sahlgren B, Johansson BL, Wahren J (1996) C-peptide stimulates rat renal tubular $\mathrm{Na}+, \mathrm{K}(+)-$ ATPase activity in synergism with neuropeptide Y. Diabetologia 39: 199-205

5. Zierath JR, Handberg A, Tally M, Wallberg-Henriksson H (1996) C-peptide stimulates glucose transport in isolated human skeletal muscle independent of insulin receptor and tyrosine kinase activation. Diabetologia 39: 306-313

6. Grunberger G, Qiang X, Li Z et al. (2001) Molecular basis for the insulinomimetic effects of C-peptide. Diabetologia 44: $1247-1257$

7. Johansson BL, Borg K, Fernqvist-Forbes E, Odergren T, Remahl S, Wahren J (1996) C-peptide improves autonomic nerve function in IDDM patients. Diabetologia 39: 687695

8. Ido Y, Vindigni A, Chang K et al. (1997) Prevention of vascular and neural dysfunction in diabetic rats by $\mathrm{C}$ - peptide. Science 277: 563-566

9. Sima AA, Zhang W, Sugimoto K et al. (2001) C-peptide prevents and improves chronic Type I diabetic polyneuropathy in the BB/Wor rat. Diabetologia 44: 889-897

10. Rigler R, Pramanik A, Jonasson P et al. (1999) Specific binding of proinsulin C-peptide to human cell membranes. Proc Natl Acad Sci USA 96: 13318-13323

11. Henriksson M, Pramanik A, Shafqat J et al. (2001) Specific binding of proinsulin C-peptide to intact and to detergentsolubilized human skin fibroblasts. Biochem Biophys Res Commun 280: 423-427

12. Pramanik A, Ekberg K, Zhong Z et al. (2001) C-peptide binding to human cell membranes: importance of glu27. Biochem Biophys Res Commun 284: 94-98

13. Ohtomo Y, Bergman T, Johansson BL, Jornvall $H$, Wahren J (1998) Differential effects of proinsulin C-peptide fragments on $\mathrm{Na}+\mathrm{K}+-$ ATPase activity of renal tubule segments. Diabetologia 41: 287-291

14. Verchere CB, Paoletta M, Neerman Arbez M et al. (1996) Des-(27-31)C-peptide. A novel secretory product of the rat pancreatic beta cell produced by truncation of proinsulin connecting peptide in secretory granules. J Biol Chem 271: 27475-27481

15. Herbert V, Lau KS, Gottlieb CW, Bleicher SJ (1965) Coated charcoal immunoassay of insulin. J Clin Endocrinol Metab 25: 1375-1384

16. Kahn SE, Halban PA (1997) Release of incompletely processed proinsulin is the cause of the disproportionate proinsulinemia of NIDDM. Diabetes 46: 1725-1732 